\title{
Mental Nursing Care for Mrs. S With Hearing Hallucinations Problem
}

\author{
Lena Selviani \\ lenaaself@gmail.com
}

\section{BAB 1}

\section{PENDAHULUAN}

\subsection{Latar Belakang}

Skizofrenia merupakan bentuk psikis yang di dalamnya terdapat gangguan utama yaitu pada bagian proses pikir yang tidak seimbang antara proses pikir, cara pikir, bahasa, dan perilaku (Direja, 2011).Skizofrenia merupakan reaksi psikotik yang berpengaruh terhadap area fungsi individu, termasuk dalam berpikir, berkomunikasi, menerima, menafsirkan kenyataan, merasakan dan menunjukkan emosi serta penyakit kronis yang ditandai dengan pikiran kacau, delusi, halusinasi, dan perilaku aneh. Skizofrenia biasanya muncul dalam masa remaja atau dewasa muda (sebelum usia 45 tahun) (Pardede \& Purba, 2020). Seseorang dikatakan menderita skizofrenia apabila perjalanan penyakitnya sudah berlangsung lewat 6 bulan, sebelumnya di dahului oleh gejala awal di sebut sebagai fase prodromal yang di tandai dengan muncul nya gejala - gejala yang tidak lazim misalnya: pikiran tidak rasional, perasaan tidak wajar, berperilaku aneh, penarikan diri, pikiran kacau, merasa tidak mampu, berbicara tidak sesuai dan sebagainya (Pardede \& Laia, 2020)..

Fenomena gangguan jiwa pada saat ini mengalami peningkatan yang sangat signifikan, dan setiap tahun di berbagai belahan dunia jumlah penderita gangguan jiwa bertambah (Pardede, \& Hasibuan, 2019). Hasil Riskesdas (2018) menunjukkan sebanyak $84,9 \%$ pengidap skizofrenia/psikosis di Indonesia. Penderita skizofrenia 70\% mengalami skizofrenia (Pardede, Keliat \& Yulia, 2015). Menurut Stuart, Keliat, dan Pasaribu (2016) halusinasi merupakan distrosi persepsi yang tidak nyata dan terjadi pada respons 
neurobiologis maladaptive, klien dengan halusinasi yang telah dikendalikan oleh halusinasinya akan melakukan perilaku yang membahayakan dirinya, orang lain, dan juga lingkungan. Pasien skizofrenia dengan masalah halusinasi, meskipun halusinasinya bervariasi tetapi sebagian besar klien skizofrenia di Rumah Sakit Jiwa mengalami halusinasi dengar diperkirakan 90\%.(Sutinah et al,2020).

Survei awal dilakukan di Yayasan Pemenang Jiwa Sumatra dengan jumlah pasien 70 orang tetapi yang menjadi subjek di dalam pembuatan askep ini berjumlah 1 orang dengan pasien masah halusinasi pendengaran atas nama inisial Ny.S, penyebabnya Ny.S sebagai subjek di karenakan pasien belum bisa mengatasi emosinya selain minum obat. Upaya yang dilakukan untuk menangani pasien halusinasi adalah dengan memberikan tidakan keperawatan yaitu membantu pasien mengenali halusinasi, isi halusinasi, waktu terjadi halusinasi, frekuensi terjadinya halusinasi, situasi yang menyebabkan halusinasi muncul dan respon klien saat halusinasi muncul. Kemuadian dengan melatih klien mengontrol halusinasi dengan menggunakan strategi pelaksanaanya itu dengan cara menghardik halusinasi, bercakap-cakap dengan orang lain, melakukan aktivitas yang terjadwal dan menggunakan obat secara teratur (Halawa, 2015). Maka tujuan asuhan keperawatan yang akan dilakukan untuk mengajarkan standar pelaksanaan masalah halusinasi pendengaran pada Ny.S.

\subsection{Rumusan Masalah}

Berdasarkan masalah yang telah di paparkan pada latar belakang maka rumusan masalah dalam askep ini yaitu Asuhan keperawatan masalah halusinasi pendengaran Ny.S, di Yayasan pemenang jiwa.

\subsection{Tujuan}

\subsubsection{Tujuan Umum}


Mahasiswa mampu memberikan asuhan keperawatan jiwa secara holistik dan komprehensif kepada Ny.S dengan gangguan persepsi sensori : halusinasi pendengaran.

\subsubsection{Tujuan Khusus}

1. Mahasiswa mampu melakukan pengkajian pada Ny.S dengan gangguan persepsi sensori : halusinasi pendengaran.

2. Mahasiswa mampu menegakkan diagnosa keperawatan yang ada pada Ny.S dengan gangguan persepsi sensori : halusinasi pendengaran.

3. Mahasiswa mampu menetapkan perencanaan keperawatan pada Ny.S dengan gangguan persepsi sensori : halusinasi pendengaran.

4. Mahasiswa mampu melakukan implementasi keperawatan pada Ny.S dengan gangguan persepsi sensori : halusinasi pendengaran.

5. Mahasiswa mampu mengevaluasi hasil asuhan keperawatan pada Ny.S dengan gangguan persepsi sensori : halusinasi pendengaran.

6. Mahasiwa mampu mendokumentasikan asuhan keperawatan yang diberikan pada Ny.S dengan gangguan persepsi sensori : halusinasi pendengaran.

\subsubsection{Manfaat}

1. Bagi Pasien Skizofrenia Mengalami Halusinasi

Pasien mampu mengontrol halusinasi dengan cara menghardik, mengontrol halusinasi dengan minum obat secara teratur, mengontrol halusinasi dengan bercakap-cakap dengan orang lain dan mengontrol halusinasi dengan kegiatan terjadwal.

2. Bagi Yayasan Pemenang Jiwa

Diharapkan dapat menjadi acuan dalam menangani dan memberikan pelayanan kepada pasien dengan gangguan jiwa dengan pasien halusinasi di Yayasaan Pemenang Jiwa Sumatera. 


\section{Bagi Ilmu Keperawatan}

Menambah keluasan ilmu terapan bidang keperawatan dalam melakukan asuhan keperawatan keluarga dengan salah satu anggota keluarga mengalami halusinasi secara langsung.

BAB 2

TINJAUAN TEORI

\subsection{Konsep Halusinasi}




\subsubsection{Defenisi}

Halusinasi pendengaran adalah mendengar suara atau kebisingan, paling sering suara orang. Suara berbentuk kebisingan yang kurang jelas sampai kata-kata yang jelas berbicara tentang klien, bahkan sampai pada percakapan lengkap antara dua orang yang mengalami halusinasi. Pikiran yang terdengar dimana klien mendengar perkataan bahwa klien disuruh untuk melakukan sesuatu kadang dapat membahayakan (azizah, 2016)

Halusinasi adalah suatu keadaan dimana seseorang mengalami perubahan dalam jumlah dan pola dari stimulus yang datang (diprakarsai) dari internal dan eksternal disertai dengan respon menurun atau dilebih-lebihkan atau kerusakan respon pada rangsangan ini (Hendarsyah, 2016).

\subsubsection{Klasifikasi Halusinasi}

Menurut Yusuf et al (2015) klasifikasi halusinasi dibagi menjadi 5 yaitu :

\begin{tabular}{|c|c|c|c|}
\hline No & $\begin{array}{l}\text { Jenis } \\
\text { halusinasi }\end{array}$ & Data Objektif & Data Subjektif \\
\hline 1 & $\begin{array}{l}\text { Halusinasi } \\
\text { Pendengaran }\end{array}$ & $\begin{array}{l}\text { 1. Bicara atau } \\
\text { tertawa sendiri } \\
\text { tanpa lawan } \\
\text { bicara } \\
\text { 2. Marah-marah } \\
\text { tanpa sebab } \\
\text { mencondongka } \\
\text { n telinga ke } \\
\text { arah tertentu } \\
\text { 3. Menutup } \\
\text { telinga }\end{array}$ & $\begin{array}{l}\text { 1. Mendengar suara atau } \\
\text { kegaduhan } \\
\text { 2. Mendengar suara yang } \\
\text { mengajak bercakap- } \\
\text { cakap } \\
\text { 3. Mendengar suara yang } \\
\text { menyuruh melakukan } \\
\text { sesuatu yang } \\
\text { berbahaya }\end{array}$ \\
\hline 2 & Halusinasi & 1. Menunjuk- & 1. Melihat \\
\hline
\end{tabular}




\begin{tabular}{|c|c|c|c|}
\hline & penglihatan & $\begin{array}{l}\text { nunjuk ke arah } \\
\text { tertentu } \\
\text { 2. Ketakutan pada } \\
\text { objek yang } \\
\text { tidak jelas }\end{array}$ & $\begin{array}{lr}\text { sinar, } & \text { bentuk } \\
\text { geometris, } & \text { bentuk } \\
\text { kartun, melihat hantu } \\
\text { atau monster }\end{array}$ \\
\hline 3 & $\begin{array}{l}\text { Halusinasi } \\
\text { penghindu }\end{array}$ & $\begin{array}{l}\text { 1. Menghindu } \\
\text { seperti sedang } \\
\text { membaui bau- } \\
\text { bauan tertentu } \\
\text { 2. Menutup } \\
\text { hidung }\end{array}$ & $\begin{array}{l}\text { 1. Membaui bau-bauan } \\
\text { seperti bau darah, } \\
\text { urine, feses, } \\
\text { 2. kadang-kadang bau itu } \\
\text { menyenangkan }\end{array}$ \\
\hline 4 & $\begin{array}{l}\text { Halusinasi } \\
\text { pengecepan }\end{array}$ & $\begin{array}{l}\text { 1. Sering meludah } \\
\text { 2. Muntah }\end{array}$ & $\begin{array}{l}\text { 1. Merasakan rasa seperti } \\
\text { darah, urine, feses }\end{array}$ \\
\hline 5 & $\begin{array}{l}\text { Halusinasi } \\
\text { perabaan }\end{array}$ & $\begin{array}{l}\text { Menggaruk-garuk } \\
\text { permukaan kulit }\end{array}$ & $\begin{array}{l}\text { 1. Mengatakan ada } \\
\text { serangga di permukaan } \\
\text { kulit } \\
\text { 2. Merasa seperti } \\
\text { tersengat listrik }\end{array}$ \\
\hline
\end{tabular}

\subsubsection{Tanda dan Gejala}

Tanda dan gejala halusinasi dinilai dari hasil observasi terhadap pasien serta ungkapan pasien menurut (Pardede et al, 2021) :

1. Menyeringai atau tertawa yang tidak sesuai

2. Menggerakkan bibirnya tanpa menimbulkan suara

3. Gerakan mata cepat

4. Menutup telinga

5. Respon verbal lambat atau diam

6. Diam dan dipenuhi oleh sesuatu yang mengasyikkan

7. Terlihat bicara sendiri

8. Menggerakkan bola mata dengan cepat

9. Bergerak seperti membuang atau mengambil sesuatu 
10. Duduk terpaku, memandang sesuatu, tiba-tiba berlari ke ruangan lain

11. Disorientasi (waktu, tempat, orang)

12. Perubahan kemampuan dan memecahkan masalah

13. Perubahan perilaku dan pola komunikasi

14. Gelisah, ketakutan, ansietas

15. Peka rangsang

16. Melaporkan adanya halusinasi

\subsubsection{Etiologi}

1. Halusinasi yang dialami oleh individu dapat disebabkan melalui faktor presdisposisi dan presipitasi. Hal ini didukung oleh pernyataan dari Stuart, Keliat, \& Pasaribu (2016) penyebab munculnya halusinasi ada dua yaitu faktor predisposisi dan presipitasi. Faktor predisposisi terdiri dari

1. faktor biologis yang berhubungan dengan perkembangan sistem saraf yang tidak normla,

2. Faktor psikologis seperti pola asuh orang tua, kondisi keluarga dan lingkungan,

3. Faktor sosial budaya seperti kondisi ekonomi, konflik sosial, serta kehidupan yang terisolasi disertai stres. Sedangkan faktor lainnya yaitu presipitasi yakni faktor biologi yang terkait dalam gangguan komunikasi dan putaran balik otak yang mengatur proses informasi,

4. Faktor lingkungan yang mana terjadi tingkat stresor lingkungan di luar batas toleransi individu,

5. Koping yang dapat menentukan seseorang dalam mentoleransi stressor

2. Faktor presipitasi

Faktor presipitasi merupakan stimulus yang dipersepsikan oleh individu sebagai tantangan, ancaman, atau tuntutan yang memerlukan energi ekstra untuk menghadapinya. Seperti adanya 
rangsangan dari lingkungan, misalnya partisipasi klien dalam kelompok, terlalu lama tidak diajak komunikasi, objek yang ada di lingkungan dan juga suasana sepi atau terisolasi, sering menjadi pencetus terjadinya halusinasi. Hal tersebut dapat meningkatkan stress dan kecemasan yang merangsang tubuh mengeluarkan zat halusinogenik. Penyebab Halusinasi dapat dilihat dari lima dimensi yaitu :

a. Dimensi fisik

Halusinasi dapat ditimbulkan oleh beberapa kondisi fisik seperti kelelahan yang luar biasa, penggunaaan obat-obatan, demam hingga delirium, intoksikasi alkohol dan kesulitan untuk tidur dalam waktu yang lama.

b. Dimensi Emosional

Perasaan cemas yang berlebihan atas dasar problem yang tidak dapat diatasi merupakan penyebab halusinasi itu terjadi. Isi dari halusinasi dapat berupa perintah memaksa dan menakutkan. Klien tidak sanggup lagi menentang perintah tersebut hingga dengan kondisi tersebut klien berbuat sesuatu terhadap ketakutan tersebut.

c. Dimensi Intelektual

Dalam dimensi intelektual ini menerangkan bahwa individu dengan halusinasi akan memperlihatkan adanya penurunan fungsi ego. Pada awalnya halusinasi merupakan usaha dari ego sendiri untuk melawan impuls yang menekan, namun merupakan suatu hal yang menimbulkan kewaspadaan yang dapat mengambil seluruh perhatian klien dan tidak jarang akan mengontrol semua perilaku klien.

d. Dimensi Sosial

Klien mengalami interaksi sosial dalam fase awal dan comforting, klien meganggap bahwa hidup bersosialisasi di alam nyata sangat membahayakan. Klien asyik dengan Halusinasinya, seolah-olah ia merupakan tempat untuk memenuhi kebutuhan akan interaksi 
sosial, kontrol diri dan harga diri yang tidak didapatkan dakam dunia nyata.

e. Dimensi Spiritual

Secara sepiritual klien Halusinasi mulai dengan kehampaan hidup, rutinitas tidak bermakna, hilangnya aktifitas ibadah dan jarang berupaya secara sepiritual untuk menyucikan diri. Saat bangun tidur klien merasa hampa dan tidak jelas tujuan hidupnya. Individu sering memaki takdir tetapi lemah dalam upaya menjemput rezeki, menyalahkan lingkungan dan orang lain yang menyebabkan takdirnya memburuk. (Oktavia, 2020)

\subsubsection{Rentang Respon Halusinasi}

Halusinasi merupakan salah satu respon maldaptive individual yang berbeda rentang respon neurobiologi dalam Ini merupakan persepsi maladaptive. Jika klien yang sehat persepsinya akurat, mampu mengidentifisikan dan menginterpretasikan stimulus berdasarkan informasi yang diterima melalui panca indera (pendengaran, pengelihatan, penciuman, pengecapan dan perabaan) klien halusinasi mempersepsikan suatu stimulus panca indera walaupun stimulus tersebut tidak ada.Diantara kedua respon tersebut adalah respon individu yang karena suatu hal mengalami kelainan persensif yaitu salah mempersepsikan stimulus yang diterimanya, yang tersebut sebagai ilusi. Klien mengalami jika interpresentasi yang dilakukan terhadap stimulus panca indera tidak sesuai stimulus yang diterimanya, rentang respon tersebut sebagai berikut (Pardede, 2021)

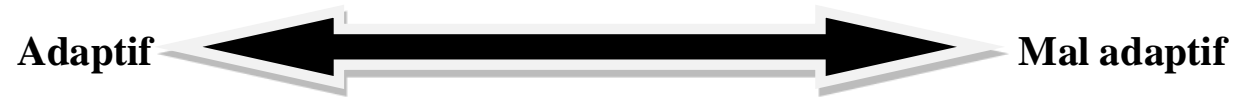

\begin{tabular}{|l|l|lr|}
\hline Pikiran logis & Kadang pikiran & Gangguan & proses \\
Persepsi akurat & terganggu & pikir/delusi & \\
Emosi konsisten & Ilusi & Halusinasi & \\
dengan pengalaman & Emosi & Tidak mampu mengalami \\
Perilaku sesuai & berlebihan/kurang & emosi & \\
\hline
\end{tabular}




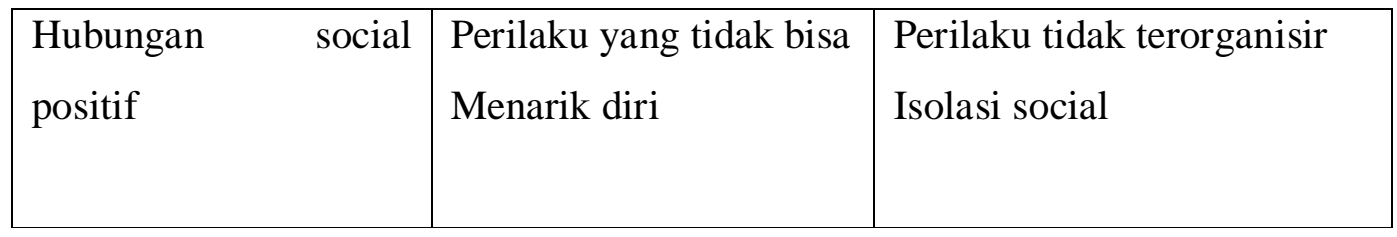

\section{Respon Adaptif}

Respon adaptif adalah respon yang dapat diterima norma-norma sosial budaya yang berlaku. Dengan kata lain individu tersebut dalam batas normal jika menghadapi suatu masalah akan dapat memecahkan masalah tersebut, respon adaptif: ( Muhith,2015).

a. Pikiran logis adalah pandangan yang mengarah pada kenyataan.

b. Persepsi akurat adalah pandangan yang tepat pada kenyataan.

c. Emosi konsisten dengan pengalaman yaitu perasaan yang timbul dari pengalaman.

d. Perilaku sosial adalah sikap dan tingkah laku yang masih dalam batas kewajaran.

e. Hubungan sosial adalah proses suatu interaksi dengan orang lain dan lingkungan.

\section{Respon Psikososial}

Respon psikosial meliputi:

a. Proses pikir terganggu adalah proses pikir yang menimbulkan gangguan.

b. Ilusi adalah interpretasi atau penilaian yang salah tentang penerapan yang benar-benar terjadi (objek nyata) karena rangsangan panca indera.

c. Emosi berlebihan atau berkurang.

d. Perilaku tidak biasa adalah sikap dan tingkah laku yang melebihi batas kewajaran.

e. Menarik diri adalah percobaan untuk menghindar interaksi dengan orang lain.

\section{Respon Maladaptif}


Respon maladaptif adalah respon individu dalam menyelesaikan masalah yang menyimpang dari norma-norma sosial budaya dan lingkungan, adapun respon maladaptif meliputi:

a. Kelainan pikiran adalah keyakianan yang secara kokoh dipertahankan walaupun tidak diyakini oleh orang lain dan bertetangan dengan kenyataan sosial.

b. Halusinasi merupakan persepsi sensori yang salah atau persepsi eksternal yang tidak realita atau tidak ada.

c. Kerusakan proses emosi adalah perubahan sesuatu yang timbul dari hati.

d. Perilaku tidak terorganisir merupakan suatu yang tidak teratur.

e. Isolasi sosial adalah kondisi kesendirian yang dialami oleh individu dan diterima sebagai ketentuan oleh orang lain dan sebagai suatu kecelakaan yang negatif mengancam.

\subsubsection{Fase Halusinasi}

Menurut Yusuf et,al (2015), karakteristik dan perilaku pasien halusinasi mengalami beberapa fase berikut :

\begin{tabular}{|c|c|c|}
\hline Level & Karakteristik pasien & Prilaku pasien \\
\hline $\begin{array}{l}\text { TAHAP } 1 \\
\text { Memberi rasa nyaman } \\
\text { tingkat ansietas } \\
\text { sedang. Secara umum } \\
\text { halusinasi merupakan } \\
\text { suatu kesenangan }\end{array}$ & 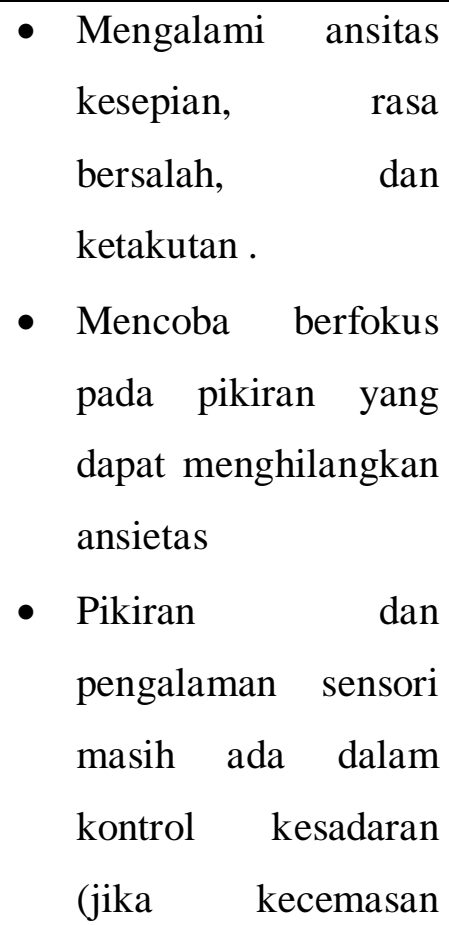 & $\begin{array}{l}\text { - } \text { Tersenyum } \\
\text { tertawa sendiri } \\
\text { - Menggerakan bibir } \\
\text { tanpa suara } \\
\text { - Penggerakan mata } \\
\text { yang cepat } \\
\text { - Respon verbal } \\
\text { yang lambat } \\
\text { - Diam dan } \\
\text { berkonsentrasi }\end{array}$ \\
\hline
\end{tabular}




\begin{tabular}{|c|c|c|}
\hline & dikontrol) & \\
\hline $\begin{array}{lr}\text { TAHAP II } & \\
\text { Menyalahkan } & \text { tingkat } \\
\text { kecemasan } & \text { berat } \\
\text { secara } & \text { umum } \\
\text { halusinasi } & \\
\text { menyebabkan } & \text { rasa } \\
\text { antipati } & \end{array}$ & 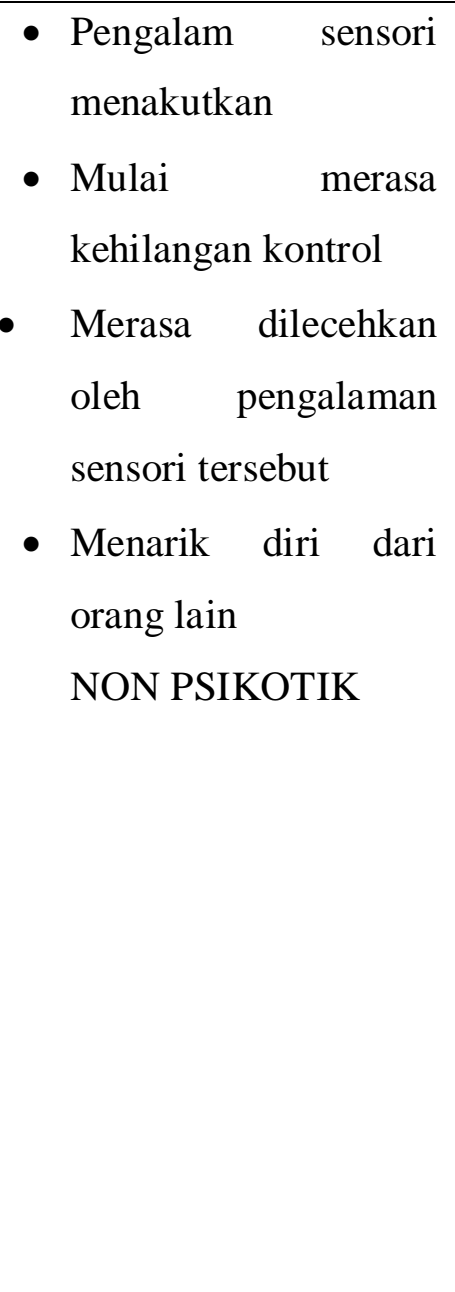 & $\begin{array}{l}\text { - Peningkatan } \\
\text { sistem saraf otak, } \\
\text { tanda-tanda } \\
\text { ansietas, seperti } \\
\text { peningkatan } \\
\text { denyut jantung, } \\
\text { pernafasan, dan } \\
\text { tekanan darah. } \\
\text { - Rentang perhatian } \\
\text { menyempit. } \\
\text { - Konsentrasi dan } \\
\text { pengalaman } \\
\text { sensori. } \\
\text { Kehilangan } \\
\text { kemampuan } \\
\text { membedakan } \\
\text { halusiasi dan } \\
\text { realita }\end{array}$ \\
\hline $\begin{array}{lr}\text { TAHAP III } \\
\text { Mengontrol tingkat } \\
\text { kecemasan } \\
\text { pengalaman sensori } \\
\text { tidak dapat di tolak } \\
\text { lagi }\end{array}$ & $\begin{array}{l}\text { - } \text { Pasien menyerah dan } \\
\text { menerima } \\
\text { pengalaman } \\
\text { sensorinya } \\
\text { - } \text { Isi halunasi menjadi } \\
\text { atraktif } \\
\text { - } \text { Kesepian } \\
\text { pengalaman sensori } \\
\text { berakhir } \\
\text { PSIKOTIK }\end{array}$ & $\begin{array}{l}\text { - Perintah halusinasi } \\
\text { ditaati } \\
\text { - Sulit berhubungan } \\
\text { dengan orang lain } \\
\text { - Rentang perhatian } \\
\text { hanaya beberapa } \\
\text { detik atau menit. } \\
\text { - Gejala fisika } \\
\text { ansietas,berat } \\
\text { berkeringat, } \\
\text { tremor, dan tidak } \\
\text { mampu mengikuti } \\
\text { perintah }\end{array}$ \\
\hline
\end{tabular}




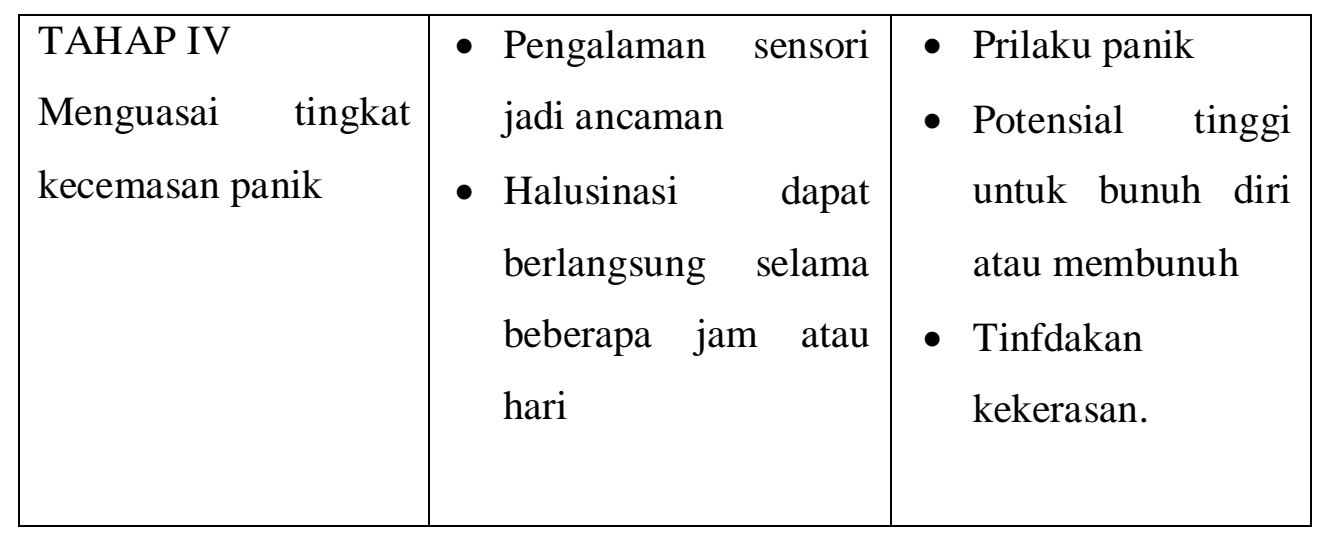

\subsubsection{Komplikasi}

Halusinasi dapat menjadi suatu alasan mengapa klien melakukan tindakan perilaku kekerasan karena suara-suara yang memberinya perintah sehingga rentan melakukan perilaku yang tidak adaptif. Perilaku kekerasan yang timbul pada klien skizofrenia diawali dengan adanya perasaan tidak berharga, takut dan ditolak oleh lingkungan sehingga individu akan menyingkir dari hubungan interpersonal dengan orang lain (Keliat, 2014). Komplikasi yang dapat terjadi pada klien dengan masalah utama gangguan sensori persepsi: halusinasi, antara lain: resiko prilaku kekerasan, harga diri rendah dan isolasi sosial.

\subsection{Konsep Dasar Asuhan Keperawatan}

\subsubsection{Pengkajian Keperawatan}

Menurut (Yusuf et al,2015), Bahwa faktor-faktor terjadinya halusinasi meliputi:

1. Faktor Predisposisi

a. Faktor perkembangan

Hambatan perkembangan akan mengganggu hubungan interpersonal yang dapat meningkatkan stres dan ansietas yang dapat berakhir dengan gangguan persepsi. Pasien mungkin menekan perasaannya sehingga pematangan fungsi intelektual dan emosi tidak efektif. 
b. Faktor sosial budaya

Berbagai faktor di masyarakat yang membuat seseorang merasa disingkirkan atau kesepian, selanjutnya tidak dapat diatasi sehingga timbul akibat berat seperti delusi dan halusinasi.

c. Faktor psikologis

Hubungan interpersonal yang tidak harmonis, serta peran ganda atau peran yang bertentangan dapat menimbulkan ansietas berat terakhir dengan pengingkaran terhadap kenyataan, sehingga terjadi halusinasi.

d. Faktor biologis

Struktur otak yang abnormal ditemukan pada pasien gangguan orientasi realitas, serta dapat ditemukan atropik otak, pembesaran ventikal, perubahan besar, serta bentuk sel kortikal dan limbik.

e. Faktor genetic

Gangguan orientasi realitas termasuk halusinasi umumnya ditemukan pada pasien skizofrenia. Skizofrenia ditemukan cukup tinggi pada keluarga yang salah satu anggota keluarganya mengalami skizofrenia, serta akan lebih tinggi jika kedua orang tua skizofrenia.

\subsubsection{Diagnosa Keperawatan}

Dengan faktor yang berhubungan dengan batasan karakteristik disesuaikan dengan keadaan yang ditemukan pada tiap-tiap partisipan. Topik yang diteliti yakni kemampuan mengontrol halusinasi pendengaran (Aji, 2019).

\subsubsection{Perencanaan Keperawatan}

Rencana tindakan Keperawatan Untuk Pasien. (Yusuf,et al,2015)

1. Tujuan tindakan untuk pasien meliputi hal berikut.

a. Pasien mengenali halusinasi yang dialaminya. 
b. Pasien dapat mengontrol halusinasinya.

c. Pasien mengikuti program pengobatan secara optimal.

2. Tindakan keperawatana.

a. Membantu pasien mengenali halusinasi dengan cara berdiskusi dengan pasien tentang isi halusinasi (apa yang didengar/dilihat), waktu terjadi halusinasi, frekuensi terjadinya halusinasi, situasi yang menyebabkan halusinasi muncul, dan respons pasien saat halusinasi muncul.

b. Melatih pasien mengontrol halusinasi. Untuk membantu pasien agar mampu mengontrol halusinasi, Anda dapat melatih pasien empat cara yang sudah terbukti dapat mengendalikan halusinasi, yaitu sebagai berikut.

1) Menghardik halusinasi.

2) Bercakap-cakap dengan orang lain.

3) Melakukan aktivitas yang terjadwal.

4) Menggunakan obat secara teratur.

Rencana tindakan keperawatan untuk keluarga.

1. Tujuan

a. Keluarga dapat terlibat dalam perawatan pasien baik di rumah sakit maupun di rumah.

b. Keluarga dapat menjadi sistem pendukung yang efektif untuk pasien.

2. Tindakan keperawatan

a. Diskusikan masalah yang dihadapi keluarga dalam merawat pasien.

b. Berikan pendidikan kesehatan tentang pengertian halusinasi, jenis halusinasi yang dialami pasien, tanda dan gejala halusinasi, proses terjadinya halusinasi, serta cara merawat pasien halusinasi. 
c. Berikan kesempatan kepada keluarga untuk memperagakan cara merawat pasien dengan halusinasi langsung di hadapan pasien.

d. Buat perencanaan pulang dengan keluarga.

\subsubsection{Implementasi}

Implementasi disesuaikan dengan rencana tindakan keperawatan. Pada situasi nyata sering pelaksanaan jauh berbeda dengan rencana, hal ini terjadi karena perawat belum terbiasa menggunakan rencana tertulis dalam melaksanakan tindakan keperawatan. Sebelum melaksanakan tindakan keperawatan yang sudah direncanakan, perawat perlu memvalidasi dengan singkat apakah rencana tindakan masih sesuai dan dibutuhkan klien sesuai dengan kondisinya (here and now). Perawat juga menilai diri sendiri, apakah kemampuan interpersonal, intelektual, tekhnikal sesuai dengan tindakan yang akan dilaksanakan, dinilai kembali apakah aman bagi klien. Setelah semuanya tidak ada hambatan maka tindakan keperawatan boleh dilaksanakan.

Adapun pelaksanaan tindakan keperawatan jiwa dilakukan berdasarkan Strategi Pelaksanaan (SP) yang sesuai dengan masingmasing masalah utama. Pada masalah gangguan sensori persepsi: halusinasi pendengaran, terdapat 2 jenis SP, yaitu SP Klien dan SP Keluarga.

SP klien terbagi menjadi SP 1 (membina hubungan saling percaya, mengidentifikasi halusinasi "jenis, isi, waktu, frekuensi, situasi, perasaan dan respon halusinasi", mengajarkan cara menghardik, memasukan cara menghardik ke dalam jadwal; SP 2 (mengevaluasi SP 1, mengajarkan cara minum obat secara teratur, memasukan ke dalam jadwal); SP 3 (mengevaluasi SP 1 dan SP 2, menganjurkan klien untuk mencari teman bicara); SP 4 (mengevaluasi SP 1, SP 2, dan SP 3, melakukan kegiatan terjadwal). 
SP keluarga terbagi menjadi SP 1 (membina hubungan saling percaya, mendiskusikan masalah yang dihadapi keluarga dalam merawat pasien, menjelaskan pengertian, tanda dan gejala helusinasi, jenis halusinasi yang dialami klien beserta proses terjadinya, menjelaskan cara merawat pasien halusinasi); SP 2 (melatih keluarga mempraktekan cara merawat pasien dengan halusinasi, melatih keluarga melakukan cara merawat langsung kepada pasien halusinasi); SP 3 (membantu keluarga membuat jadwal aktivitas di rumah termasuk minum obat (discharge planing), menjelaskan follow up pasien setelah pulang).

Pada saat akan dilaksanakan tindakan keperawatan maka kontrak dengan klien dilaksanakan dengan menjelaskan apa yang akan dikerjakan dan peran serta klien yang diharapkan, dokumentasikan semua tindakan yang telah dilaksanakan serta respon klien.

\subsubsection{Evaluasi Keperawatan}

Evaluasi adalah proses hasil atau sumatif dilakukan dengan membandingkan respon klien pada tujuan umum dan tujuan khusus yang telah ditentukan.halusinasi pendengaran tidak terjadi perilaku kekerasan, klien dapat membina hubungan saling percaya, klien dapat mengenal halusinasinya, klien dapat mengontrol halusinasi dengar dari jangka waktu 4x24 jam didapatkan data subjektif keluarga menyatakan senang karena sudah diajarkan teknik mengontrol halusinasi, keluarga menyatakan pasien mampu melakukan beberapa teknik mengontrol halusinasi. Data objektif pasien tampak berbicara sendiri saat halusinasi itu datang, pasien dapat berbincang-bincang dengan orang lain, pasien mampu melakukan aktivitas terjadwal, dan minum obat secara teratur ( Aji, 2019 ) 


\section{BAB 3}

\section{TINJAUAN KASUS}

\subsection{Identitas Klien}

Inisial

Tanggal Pengkajian

Umur

Agama

Informan
: Ny.S

: 2 maret 2021

: 42 Tahun

: Kristen

: Klien dan penjaga pasien di yayasan

\subsection{Alasan Masuk Rumah Sakit}

Klien suka menyendiri,melamun,mondar mandir, gelisah, dan mendengar suara-suara tanpa wujud.

\subsection{Faktor Predisposisi}

Klien pernah di rawat di RSJ Bina Karsa Medan sebelumnya pada tahun 2019 yang lalu di rawat hanya 4 hari. Di rumah klien tidak rutin minum obat. Semenjak di rumah Klien tidak pernah Kontrol ke RSJ ataupun klinik Jiwa, sehingga timbul gejala di atas, pasien mengosumsi obat yaitu :

Resperidon (2X1)

Clozapine $25 \mathrm{mg}(1 \mathrm{x} 1)$

\subsection{Fisik}

Tanda vital

TD : 110/90 mmHg, N : 97 x/I, S : $36{ }^{0} \mathrm{C}, \mathrm{P}: 20$ x/i

TB : $152 \mathrm{~cm}, \mathrm{BB}: 50 \mathrm{Kg}$

Klien tidak memiliki keluhan fisik. 


\subsubsection{Genogram}
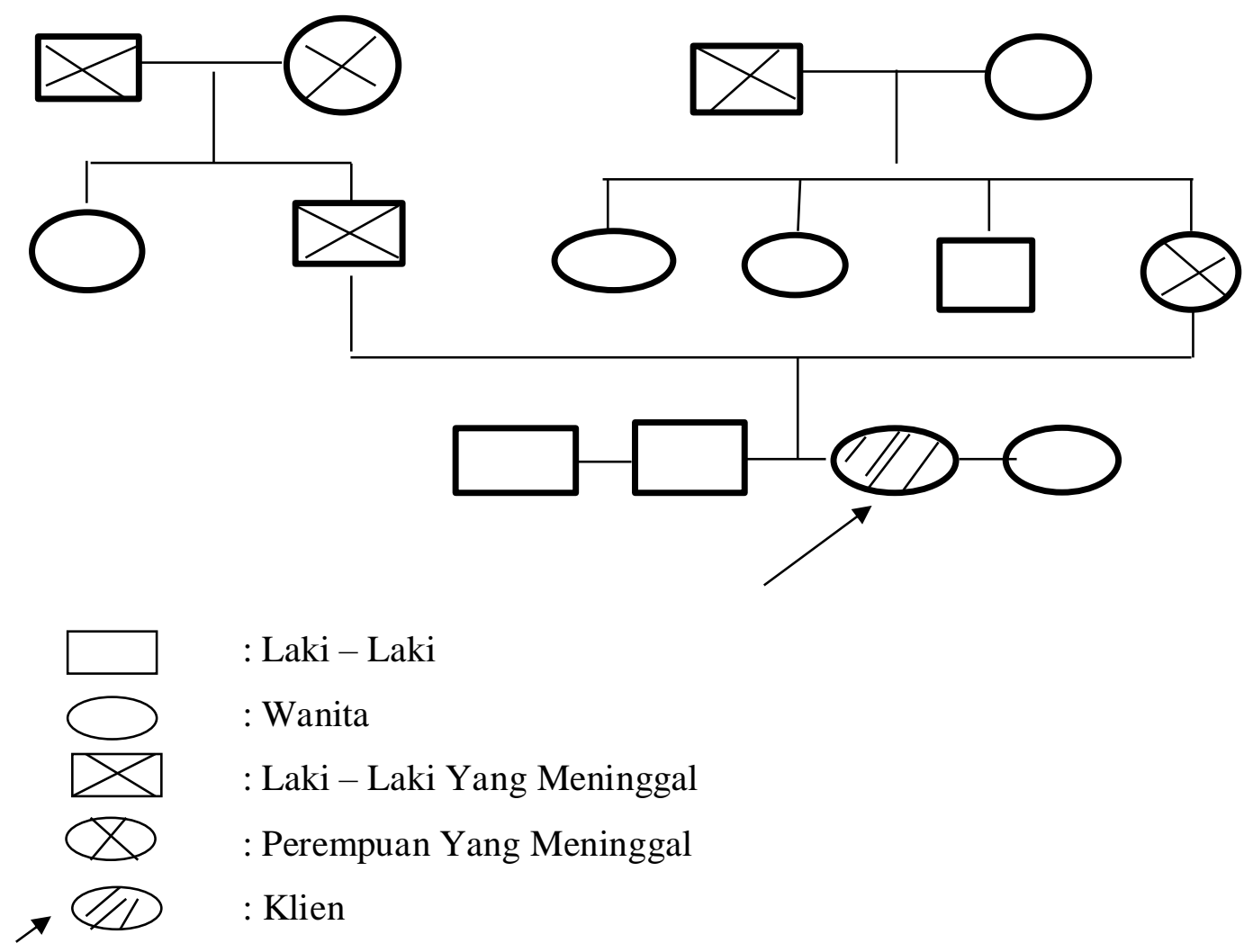

Berdasarkan genogram di atas, dapat dilihat bahwa klien merupakan anak ke 2 dari 4 bersaudara, tidak ada riwayat keluarga yang mengalami gangguan jiwa. Klien belum menikah.

\subsubsection{Konsep diri}

1. Gambaran diri : Klien menyukai keseluruhan bagian tubuhnya

2. Identitas Diri: Klien memiliki latar belakang pendidikan terakhir SMP, sebelum dirawat di RSJ klien pernah bekerja sebagai penjaga toko dan klien merasa senang dengan pekerjaannya.

3. Peran Diri : Klien sebagai sebagai anak, klien merasa tidak berguna karena tidak dapat membantu keluarga.

4. Ideal diri : Klien mengatakan malu bahwa dia memiliki gangguan jiwa dan tidak bekerja lagi, klien berharap segera sembuh dan bekerja kembali, klien sedih dan putus asa karena penyakitnya tak 
kunjung sembuh dan klien merasa tidak di pedulikan keluarga karena jarang di jenguk.

5. Harga diri : klien merasa tidak berguna karena dirawat diyayasan jiwa

Masalah keperawatan : Gangguan Konsep Diri : Harga diri rendah

\subsubsection{Hubungan Sosial}

1. Orang yang berarti :adik

2. Peran serta dalam kegiatan kelompok / masyarakat : Tidak berperan dalam kegiatan sosial

3. Hambatan dalam berhubungan dengan orang lain : klien mengatakan tidak berminat untuk terlalu banayak berkomunikasi dengan pasien yang lain

\subsubsection{Spiritual}

1. Nilai dan keyakinan : Klien menganut agam Budha dan pasien mempercayai adanya TUHAN.

2. Kegiatan ibadah : Klien selama dirawat sering beribadah . Masalah keperawatan: tidak ada Masalah keperawatan

\subsubsection{Status Mental}

1. Klien berpenampilan kurang rapi dan kurang bersih dalam berpakaian

2. Klien menjawab setiap pertanyaan dengan lambat sesuai dengan yang ditanyakan oleh perawat.

3. Klien mampu melakukan aktivitas sehari-hari seperti merapikan kamar, mencuci piring, dan mandi sendiri.

4. Klien merasa sedih dan putus asa karena tidak kunjung sembuh, merasa tidak berguna karena tidak dapat membantu keluarga, klien merasa malu karena di rawat di yayasan pemenang jiwa.

Masalah Keperawatan: Harga diri rendah

5. Klien tidak Labil 
6. Selama proses interaksi, klien cukup kooperatif serta kontak mata baik antara perawat-klien

7. Klien ketakutan saat mengalamihalusinasi pendengaran yaitumendengar suara-suara menyuruhnya untuk minum air putih Timbul pada saat sendiri dan terjadi pada sore hari.

Masalah Keperawatan : Gangguan Persepsi Sensori : Halusinasi pendengaran

8. Klien mengutarakan pendapat dengan baik

9. Klien menyampaikan isi pikir sesuai dengan pertanyaan

10. Klien dalam keadaan sadar (Composmentis) serta memiliki orientasi yang baik terkait orang, tempat, waktu.

11. Klien mampu mengingat hal-hal yang terjadi di masa lalu

12. Klien mampu fokus pada topik pembicaraan.

13. Klien mampu membedakan yang baik dan buruk dalam kegiatan seharihari

14. Daya tilik diri yakni klien menyadari bahwa dirinya mengalami gangguan jiwa halusinasi dan ingin segera sembuh.

\section{a. Masalah Psikososial Dan Lingkungan}

Klien memiliki masalah dalam berhubungan dengan lingkungan karena stigma masyarakat terhadap dirinya yang dirawat di yayasan pemenang jiwa.

Masalah Keperawatan:Isolasi Sosial

b. Aspek Medik

Diagnosa Medik : Skizofrenia Paranoid

Terapi Medik : Risperidon 2 mg (2 x 1$)$

Clozapine $25 \mathrm{mg}(1 \mathrm{x} 1)$ 


\section{c. Analisa Data}

\begin{tabular}{|c|c|}
\hline Data & Masalah Keperawatan \\
\hline $\begin{array}{l}\text { DS : } \\
\text { - Pengurus yayasan mengatakan } \\
\text { bahwa klien sering berteriak } \\
\text { - } \text { Klien sering mendengarkan } \\
\text { suara-suara tanpa wajah yang } \\
\text { menyuruhnya untuk selalu pergi } \\
\text { saja } \\
\text { - Klien mengatakan suara - suara } \\
\text { tersebut muncul } 3 \text { kali / hari, } \\
\text { muncul pada saat klien sedang } \\
\text { menyendiri } \\
\text { - Klien merasa gelisah dan takut } \\
\text { jika mendengar suara tersebut } \\
\text { Do : } \\
\text { Klien sering marah - marah, } \\
\text { mondar - mandir, bicara sendiri, } \\
\text { bicara ngawur, sering senyum - } \\
\text { senyum sendiri }\end{array}$ & $\begin{array}{l}\text { Gangguan Persepsi Sensori : Halusinasi } \\
\text { pendengaran }\end{array}$ \\
\hline $\begin{array}{l}\text { Ds: } \\
\text { Klien mengatakan tidak mengikuti } \\
\text { kegiatan di kelompok/masyarakat. } \\
\text { Klien mengatakan mempunyai } \\
\text { hambatan dalam berhubungan } \\
\text { dengan orang lain karena klien sulit } \\
\text { bergaul dan selalu ingin menyendiri. } \\
\text { Do : } \\
\text { Klien tampak menghindari interaksi, } \\
\text { terlihat sedih, pendangan menunduk } \\
\text { kebawah }\end{array}$ & Isolasi Sosial: Menarik Diri \\
\hline
\end{tabular}




\section{d. Daftar Masalah Keperawatan}

1. Gangguan Persepsi Sensori : Halusinasi pendengaran

2. Isolasi sosial : Menarik diri

\section{e. Pohon Masalah}

\section{Halusinasi Pendengaran}

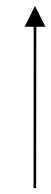

Isolasi Sosial 


\section{f. Diagnosa Keperawatan}

1. Gangguan Persepsi Sensori : Halusinasi pendengaran

2. Isolasi sosial : menarik diri

\section{g. Implementasi dan Evaluasi Keperawatan}

\begin{tabular}{|c|c|c|}
\hline WAKTU & Implentasi & Evaluasi \\
\hline $\begin{array}{lr}\text { Selasa } & 02 \\
\text { Februari } \\
2021 & 10.00 \\
\text { WIB }\end{array}$ & $\begin{array}{l}\text { 1. Data } \\
\text { Tanda dan gejala :bicara sendiri, marah - marah } \\
\text { tampa sebab, memalingkan muka ke arah telingga, } \\
\text { ketakutan pada suatu yang tidak jelas, } \\
\text { 2.Diagnosa Keperawatan } \\
\text { Husinasi pendengaran } \\
\text { 3.Tindakan Keperawatan } \\
\text { Sp1 halusinasi } \\
\text { - Melatih pasien mengidentifikasi halusinasinya; } \\
\quad \text { isi, frekuensi, watu terjadi, sruasi pencetus, } \\
\quad \text { perasaan dan respon halusinasi } \\
\text { - Mengontrol halusinasi dengan cara menghardik } \\
\text { 4. RTL } \\
\text { Sp2; mengontrol halusinasi dengan cara minum obat }\end{array}$ & 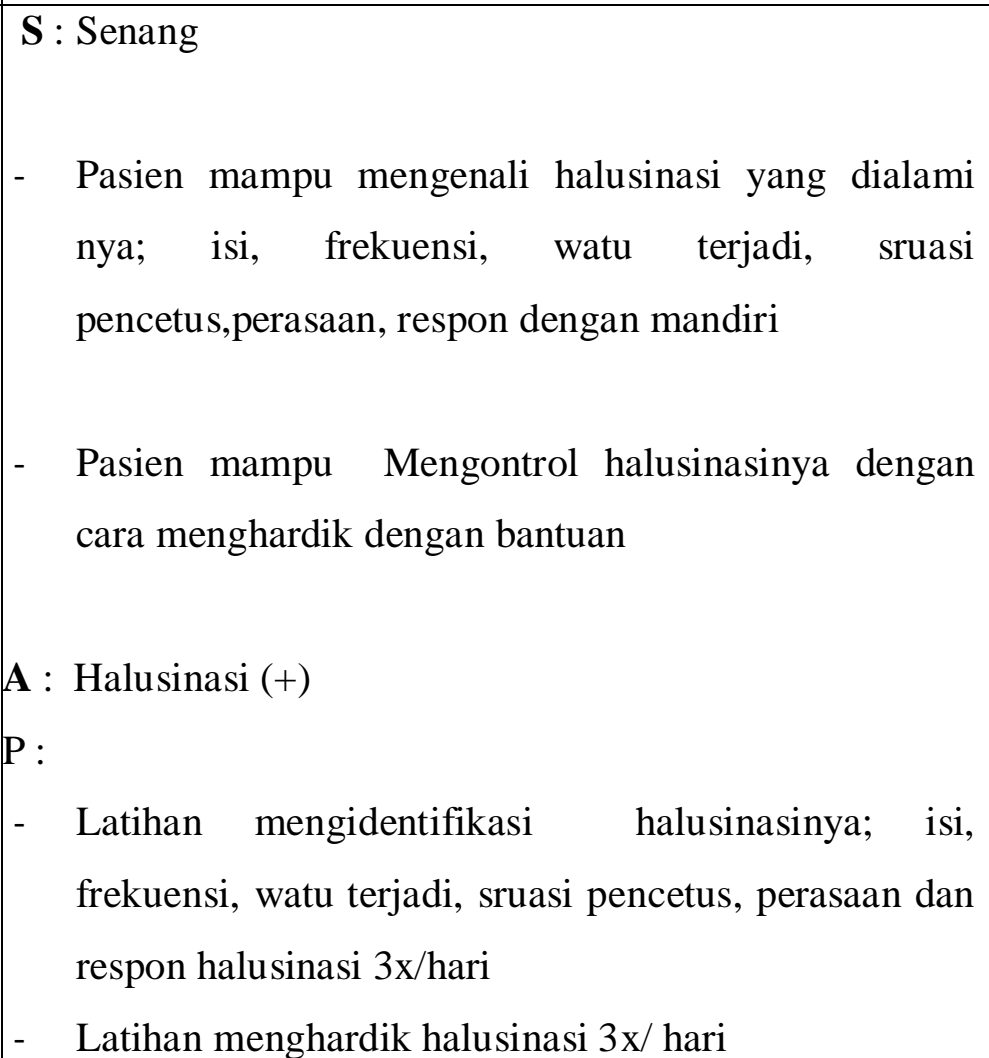 \\
\hline
\end{tabular}




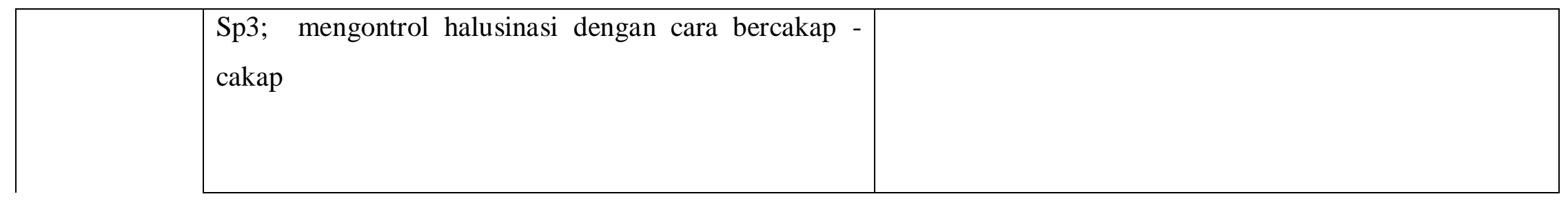




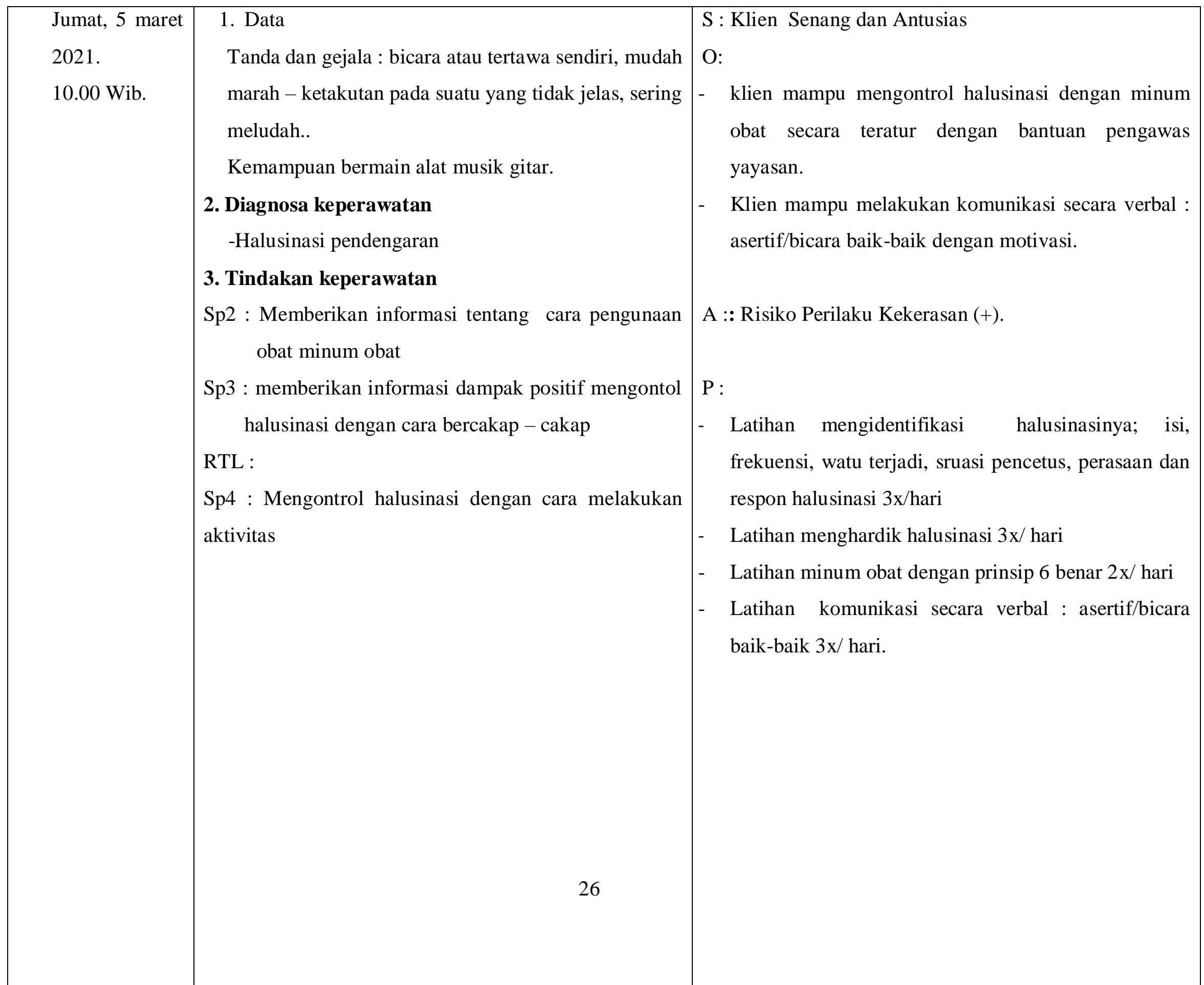




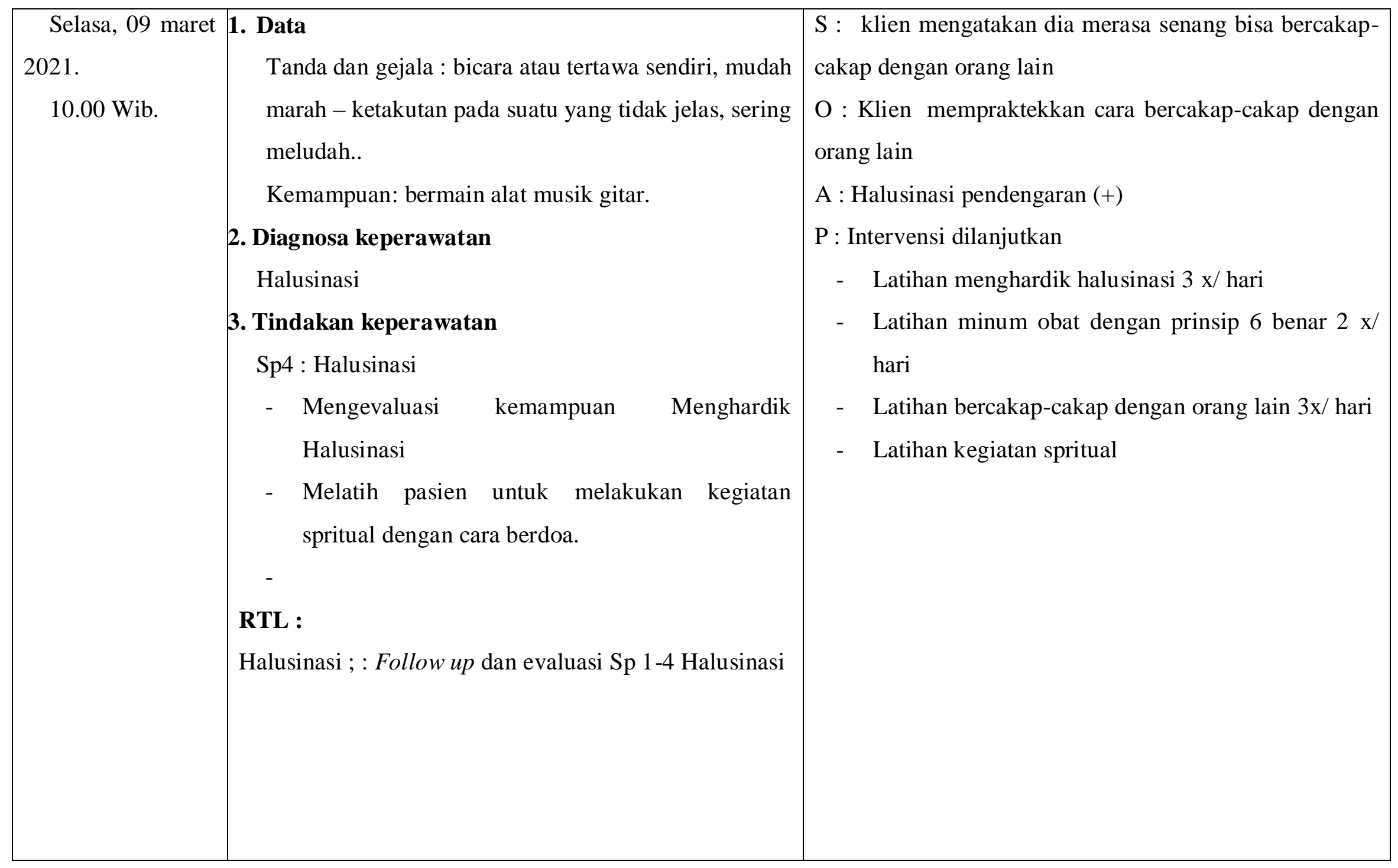




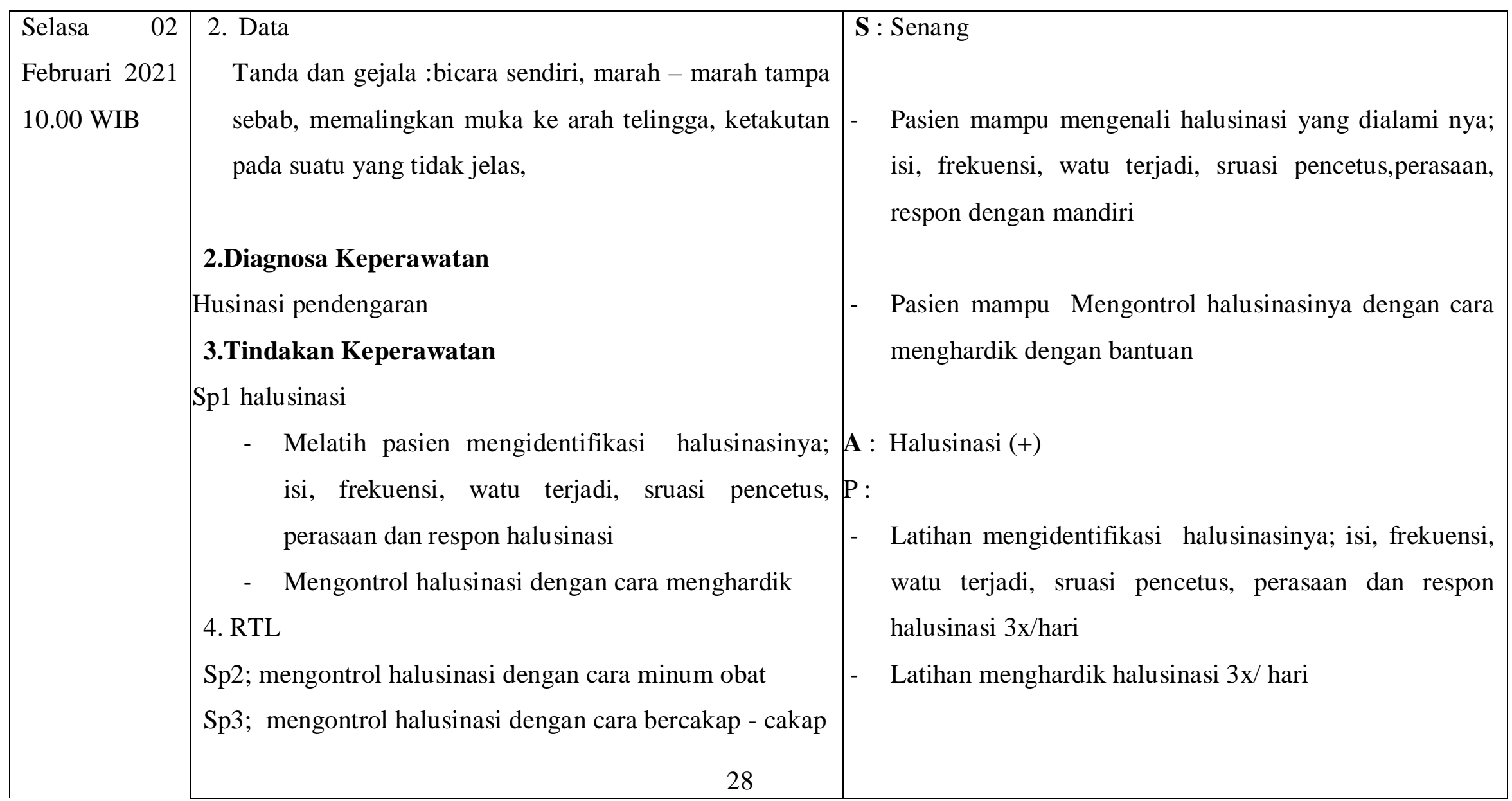




\begin{tabular}{|c|c|c|}
\hline Isolasi Sosial & $\begin{array}{l}\text { Ekspresi wajah bersahabat, menunjukkan rasa senang, } \\
\text { ada kontak mata, mau berjabat tangan, mau } \\
\text { menyebutkann nama, mau menjawab salam, klien mau } \\
\text { duduk berdampingan dengan perawat, mau mengutarakan } \\
\text { masalah yang di } \\
\text { hadapi. }\end{array}$ & $\begin{array}{l}\text { 1.Bina hubungan saling percaya dengan mengungkapkan } \\
\text { prinsip komunikasi terapeutik: } \\
\text { a. Sapa klien dengan ramah, baik verbal maupun non } \\
\text { verbal } \\
\text { b. Perkenalkan diri dengan sopan } \\
\text { c. Tanyakan nama lengkap klien \& nama panggilan } \\
\text { yang disukai klien } \\
\text { d. Jelaskan tujuan pertemuan } \\
\text { e. Jujur dan menepati janji } \\
\text { f. Tunjukkan sikap empati dan menerima klien apa } \\
\text { adanya } \\
\text { g. Beri perhatian pada klien dan perhatian kebutuhan } \\
\text { dasar pasien } \\
\text { 2. Klien dapat menyebutkan penyebab menarik diri } \\
\text { a. Kaji perilaku klien tentang perilaku menarik diri dan } \\
\text { tanda-tandanya. } \\
\text { b. Beri kesempatan kepda klien untuk mengungkapkan } \\
\text { perasaan penyebab menarik diri atau tidak mau bergaul. } \\
\text { c. Diskusikan bersama klien tentang perilaku menarik diri, } \\
\text { tanda-tanda serta penyebab yang muncul. }\end{array}$ \\
\hline
\end{tabular}




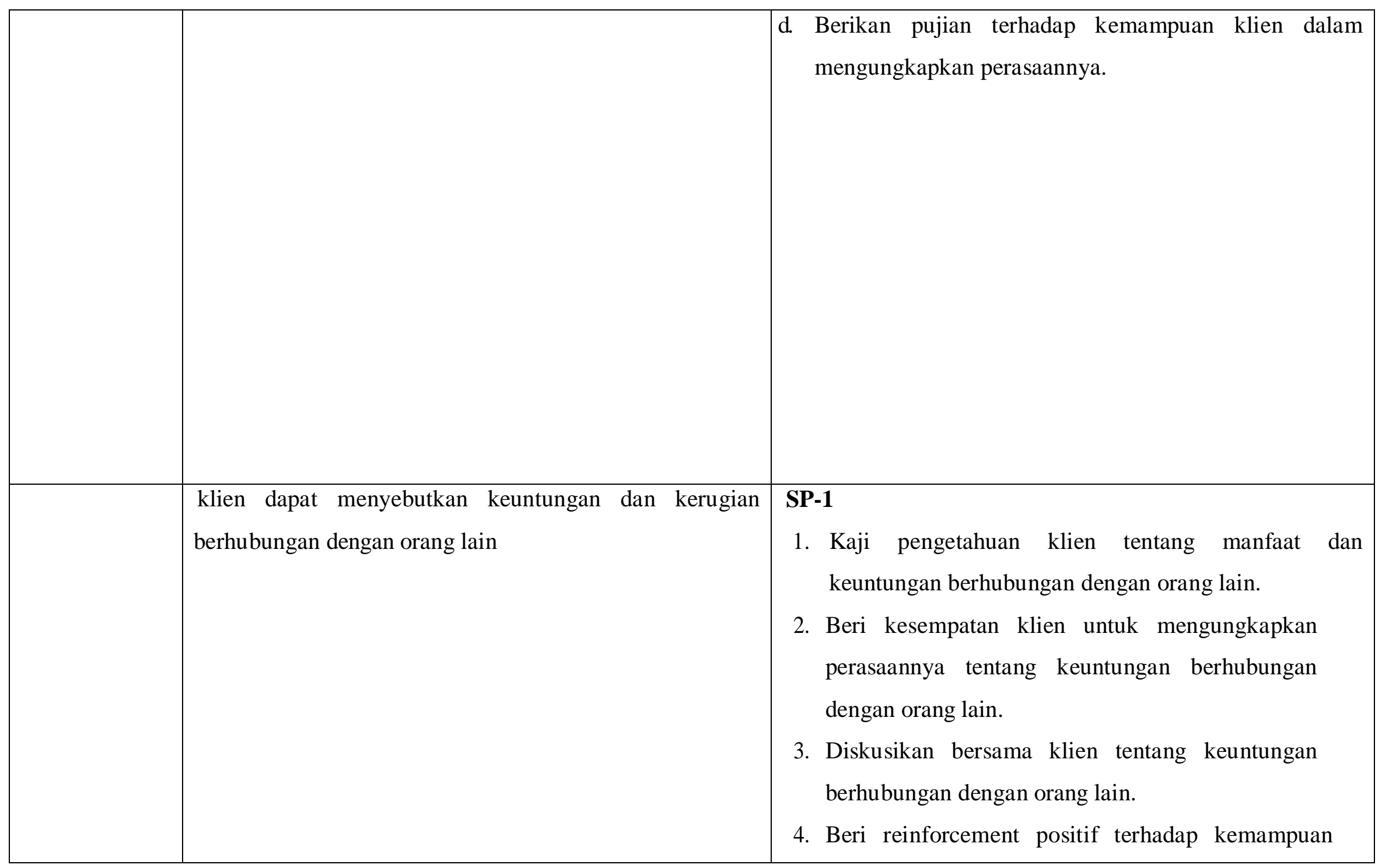




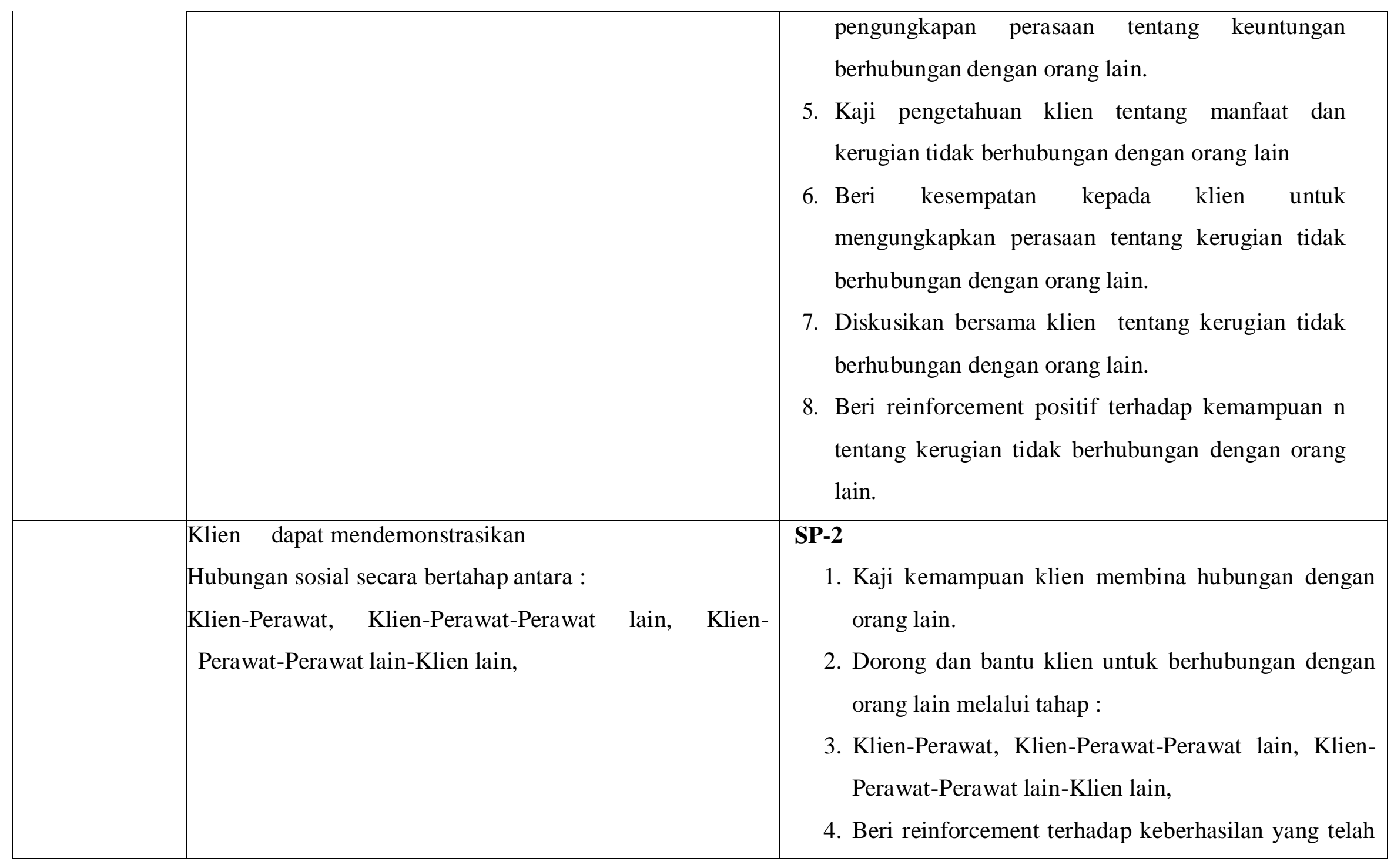




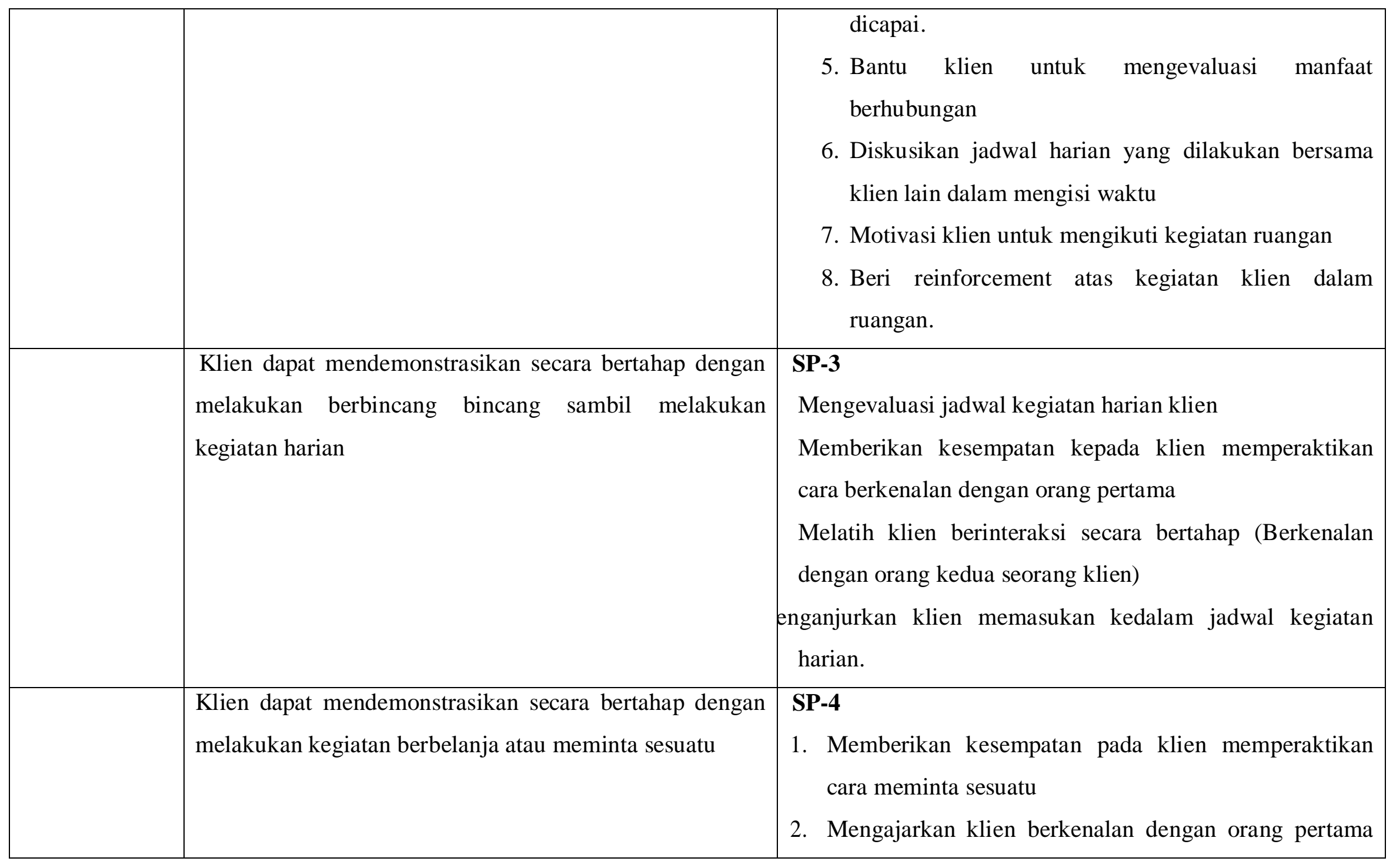




\begin{tabular}{|c|c|c|}
\hline & & (seorang perawat). \\
\hline $\begin{array}{l}\text { Harga diri } \\
\text { rendah kronis }\end{array}$ & Kemampuan yang dimiliki klien & $\begin{array}{l}\text { SP1 : mengidentifikasi aspek positif yang dimilki klien } \\
\text { SP2 : } \\
\text { a. Menilai kemampuan yang dapat digunakann } \\
\text { b. Menetapkan/ memilih kegiatan sesuai kemampuan } \\
\text { c. Melatih kegiatan sesuai dengan kemampuan yang } \\
\text { dipilih } \\
\text { SP3 : mengidentifikasi aspek postif yang dimilki klien } 2 \\
\text { SP4 : mengidentifikasi aspek positif yang dimilki klien } 3\end{array}$ \\
\hline
\end{tabular}




\section{BAB 4 \\ PEMBAHASAN}

Setelah penulis melaksanakan asuhan keperawat kepada Ny.S dengan gangguan sensori persepsi: halusinasi pendengaran di Yayasan Pemenang Jiwa maka penulis pada BAB ini akan membahasan kesenjangan antara teoritis dengan tinjauan kasus. Pembahasan dimulai melalui tahapan proses keperawatan yaitu pengkajian, diagnosa keparawatan, perencanaan, pelaksanaan dan evaluasi.

\subsection{Pengkajian}

Pada pembahasan ini diuraikan tentang hasil pelaksanaan tindakan keperawatan dengan pemberian terapi generalis pada klien halusinasi pendengaran. Pembahasan menyangkut analisis hasil penerapan terapi generalis terhadap masalah keperawatan halusinasi pendengaran. Tindakan keperawatan didasarkan pada pengkajian dan diagnosis keperawatan yang terdiri dari tindakan generalis yang dijabarkan sebagai berikut.

Tahap pengkajian pada klien halusinasi dilakukan interaksi perawat-klien melalui komunikasi terapeutik untuk mengumpulkan data dan informasi tentang status kesehatan klien. Pada tahap ini terjadi proses interaksi manusia, komunikasi, transaksi dengan peran yang ada pada perawat sebagaimana konsep Peplau tentang manusia yang bisa dipengaruhi dengan adanya proses interpersonal.

Selama pengkajian dilakukan pengumpulan data dari beberapa sumber, yaitu dari pasien dan tenaga kesehatan di ruangan. Penulis mendapat sedikit kesulitan dalam menyimpulkan data karena keluarga pasien jarang mengunjungi pasien di yayasan. Maka penulis melakukan pendekatan kepada pasien melalui komunikasi terapeutik yang lebih terbuka membantu pasien untuk memecahkan perasaannya dan juga melakukan observasi kepada pasien.

Adapun upaya tersebut yaitu:

1. Melakukan pendekatan dan membina hubungan saling percaya diri pada klien agar klien lebih terbuka dan lebih percaya dengan menggunakan perasaan.

2. Mengadakan pengkajian klien dengan wawancara

3. Mengadakan pengkajian dengan cara berbicara dengan pasien dan petugas yayasan. 
Dalam pengkajian ini, penulis tidak menemukan kesenjangan karena ditemukan hal sama seperti pada tinjauan teoritis. Pada kasus Ny.S, mendengar suara-suara yang tidak jelas yang menggunya sehingga meresahkan orang lain, timbul pada saat sendiri atau melamun dan tidak menentu, timbul 3 kali/hari, gelisah bila melihat halusinasi tersebut,menumpahkan air, Bicara sendiri, sulit tidur, muka tegang. Gejala gejala tersebut merupakan manifestasi klinis dari halusnasi (Keliat, dkk.2014). Selain itu terdapat faktor predisposisi maupun presipitasi yang menyebabkan kekambuhan penyakit yang dialami oleh Ny.S.

Tindakan keperawatan terapi generalis yang dilakukan pada Ny.S adalah strategi pertemuan pertama sampai pertemuan ketiga. Strategi pertemuan pertama meliputi mengidentifikasi isi, frekuensi, jenis, dan respon klien terhadap halusinasi serta melatih cara menghardik halusinasani dan melatih pasien untuk minum obat secara teratur. Strategi pertemuan kedua yang dilakukan pada Ny.S meliputi melatih cara mengendalikan dengan bercakap-cakap kepada orang lain, menyusun jadwal kegiatan bersama-sama dengan klien.

\subsection{Diagnosa Keperawatan}

Pada Teori Halusinasi (NANDA, 2015-2017), diagnosa keperawatan yang muncul sebanyak 2 diagnosa keperawatan yang meliputi:

1. Halusinasi Pendengaran

2. Risiko perilaku kekerasan

Sedangkan pada kasus Ny.S ditemukan dua diagnosa keperawatan yang muncul yang meliputi:, halusinasi, resiko perilaku kekerasan. Dari hal tersebut di atas dapat dilihat terjadi kesenjangan antara teori dan kasus. Dimana semua diagnosa pada teori muncul pada kasus Ny.S

\subsection{Implementasi}

Pada tahap implementasi, penulis hanya mengatasi 1 masalah keperawatan yakni: diagnosa keperawatan halusinasi pendengaran. Pada diagnosa keperawatan gangguan persepsi sensori halusinasi pendengaran dilakukan strategi pertemuan yaitu mengidentifikasi isi, frekuensi, waktu terjadi, perasaan, respon halusinasi. Kemudian strategi pertemuan yang dilakukan yaitu latihan mengontrol halusinasi dengan cara menghardik dan anjurkan minum obat secara teratur, strategi pertemuan yang ke dua 
yaitu latihan dengan cara bercakap-cakap pada saat aktivitas dan melatih klien melakukan semua jadwal kegiatan. Untuk melakukan implementsi pada keluarga, pada tahap-tahap diagnosa tidak dapat dilaksanakan karena penulis tidak pernah berjumpa dengan keluarga klien (keluarga tidak pernah berkunjung).

\subsection{Evaluasi}

Pada tinajauan teoritis evaluasi yang diharapkan adalah: Pasien mempercayai perawat sebagai terapis, pasien menyadari bahwa yang dialaminya tidak ada objeknya, dapat mengidentifikaasi halusinasi, dapat mengendalikan halusinasi melalui mengahrdik, latihan bercakap-cakap, melakukan aktivitas serta menggunakan obat secara teratur.

Pada tinjauan kasus evaluasi yang didapatkan adalah: Klien mampu mengontrol dan mengidentifikasi halusinasi, Klien mampu melakukan latihan bercakap-cakap dengan orang lain, Klien mampu melaksanakan jadwal yang telah dibuat bersama, Selain itu, dapat dilihat dari setiap evalusi yang dilakukan pada asuhan keperawatan, dimana terjadi penurunan gejala yang dialami oleh Ny.S dari hari kehari selama proses interaksi seperti suara halusinasi yang menyruhnya minum sebelem pemberian Sp timbul minimal 3 kali perhari setelah pemberian Sp halusinasi yang timbul hanya satu kali atau 2 kali perhari saja . 


\section{BAB 5}

\section{PENUTUP}

\subsection{Kesimpulan}

Berdasarkan uraian pada pembahasan di atas, maka penulis dapat disimpulkan bahwa:

1. Pengkajian dilakukan secara langsung pada klien dan juga dengan menjadikan status klien sebagai sumber informasi yang dapat mendukung data-data pengkajian. Selama proses pengkajian, perawat mengunakan komunikasi terapeutik serta membina hubungan saling percaya antara perawat-klien. Pada kasus Ny.S, diperoleh bahwa klien mengalami gejala-gejala halusinasi seperti Mendengar suara-suara menyuruh dia minum, timbul pada saat sendiri atau melamun dan tidak menentu, timbul minimal 3kali/hari. Gelisah bila halusinasi tersebut datang,, sulit tidur, muka tegang,tidak mampu mempertahankan kontak mata.Faktor predisposisi pada Ny.S yaitu pernah mengalami gangguan jiwa sebelumnya.

2. Diagnosa keperawatan yang muncul pada kasus Ny.S sebanyak: Halusinasi pendengaran dan isolasi sosial. Tetapi pada pelaksanaannya, penulis fokus pada masalah utama yaitu halusinasi pendengaran.

3. Perencanaan dan implementasi keperawatan disesuaikan dengan strategi pertemuan pada pasien halusinasi pendengaran.

4. Evaluasi dperoleh bahwa terjadi peningkatan kemampuan klien dalam mengendalikan halusinasi yang dialami serta dampak pada penurunan gejala halusinasi pendengaran yang dialami.

\subsection{Saran}

1. Bagi Perawat

Diharapkan dapat meenrapkan komunikasi terapeutik dalam pelaksanaan strategi pertemuan 1-4 pada klien dengan halusinasi sehingga dapat mempercepat proses pemulihan klien.

2. Bagi Rumah Sakit

Laporan ini diharapkan dapat menjadai acuan dan referensi dalam memberikan asuhan keperawatan pada klien dengan halusinasi pendengaran. 


\section{DAFTAR PUSTAKA}

1. Aji, W. M. H. (2019). Asuhan Keperawatan Orang Dengan Gangguan Jiwa Halusinasi Dengar Dalam Mengontrol Halusinasi. https://doi.org/10.31219/osf.io/n9dgs

2. Manao, B. M., \& Pardede, J. A. (2019). Correlation of Family Burden of The Prevention of Recurrence of Schizophrenia Patients. Mental Health, 4(1), 31-42.

3. Azizah.L.M., Zainuri. I., \& Akbar.A. (2016). Buku Ajar Keperawatan Kesehatan Jiwa. Yogyakarta: Indomedia Pustaka.

4. Halawa. A. (2015). Pengaruh Terapi Aktivitas Kelompok: Stimulasi Persepsi Sesi 1-2 Terhadap Kemampuan Mengontrol Halusinasi Pendengaran Pada Pasienskizofrenia Di Ruang Flamboyan Rumah Sakit Jiwamenur Surabaya. Jurnal Keperawatan, 4(1), 3037. https://doi.org/10.47560/kep.v4i1.185

5. Pardede, J. A., Harjuliska, H., \& Ramadia, A. (2021). Self-Efficacy dan Peran Keluarga Berhubungan dengan Frekuensi Kekambuhan Pasien Skizofrenia. Jurnal Ilmu Keperawatan Jiwa, 4(1), 57-66.

6. Pardede, J. A., Keliat, B. A., \& Wardani, I. Y. (2013). Pengaruh Acceptance And Commitment Therapy Dan Pendidikan Kesehatan Kepatuhan Minum Obat Terhadap Gejala, Kemampuan Berkomitmen Pada Pengobatan Dan Kepatuhan Pasien Skizofrenia. FIK UI, Depok.

7. Muhith, Abdul. (2015). Pendidikan Keperawatan Jiwa Teori Dan Aplikasi. Yogyakarta : CV Andi Offset

8. Pardede, J. A. (2020). Ekspresi emosi keluarga yang merawat pasien skizofrenia. $\begin{array}{llll}\text { Jurnal Ilmiah Keperawatan Imelda, 6(2), } & \text { 117-122. }\end{array}$ https://doi.org/10.2411/jikeperawatan.v6i2.403

9. Pardede, J. A., \& Purba, J. M. (2020). Family Support Related to Quality of Life on Schizophrenia Patients. Jurnal Ilmiah Permas: Jurnal Ilmiah STIKES Kendal, 10(4), 645-654. https://doi.org/10.32583/pskm.v10i4.942

10. Keliat, B.A \& Akemat. 2014. Model Praktik Keperawatan Profesional Jiwa. Jakarta EGC

11. Muhith, A.(2015)Pendidikan keperawatan jiwa: Teori dan aplikasi. Penerbit Andi.

12. Pardede, J. A., \& Hasibuan, E. K. (2019). Dukungan Caregiver Dengan Frekuensi Kekambuhan Pasien Skizofrenia. Idea Nursing Journal, 10(2). http://erepository.unsyiah.ac.id/INJ/article/view/17161

13. Direja, A. H. A. (2011). Asuhan Keperawatan Jiwa. Nuha Medika: Yogyakarta 
14. Pardede, J. A., \& Laia, B.(2020). Decreasing Symptoms of Risk of Violent Behavior in Schizophrenia Patients Through Group Activity Therapy.Jurnal Ilmu Keperawatan Jiwa, 3(3), 291-300. http://dx.doi.org/10.32584/jikj.v3i3.621

15. Yusuf. A.,Fitriasari.R., \& Nihayati. H.A.(2015). Buku Ajar Keperawatan Kesehatan Jiwa. Jakarta : Salemba Medika.

16. Pardede, J. A., Silitonga, E., \& Laia, G. E. H. (2020). The Effects of Cognitive Therapy on Changes in Symptoms of Hallucinations in Schizophrenic Patients. Indian Journal of Public Health, 11(10), 257.

17. Pardede, J.A,. (2020). Family Knowledge about Hallucination Related to Drinking Medication Adherence on Schizophrenia Patient. Jurnal Penelitian PerawatProfesional, 2(4),399-408. https://doi.org/10.37287/jppp.v2i4.183

18. Sutinah. S., Harkomah. I., \& Saswanti. N. (2020). Terapi Aktivitas Kelompok Stimulasi Persepsi Sensori (Halusinasi) Pada Klien Halusinasi Di Rumah Sakit Jiwa Provinsi Jambi. Jurnal Pengabdian Masyarakat Dalam Kesehatan. 2(2).https://ejournal.unair.ac.id/JPMK

19. Manao, B. M., \& Pardede, J. A. (2019). Beban Keluarga Berhubungan Dengan Pencegahan Kekambuhan Pasien Skizofrenia. Jurnal Keperawatan Jiwa, 12(3).

20. Pardede, J. A., Siregar, L. M., \& Hulu, E. P. (2020). Efektivitas Behaviour Therapy Terhadap Risiko Perilaku Kekerasan Pada Pasien Skizofrenia Di Rumah Sakit Jiwa Prof. Dr. Muhammad Ildrem Provsu Medan. Jurnal Mutiara Ners, 3(1), 8-14.

21. Stuart, G. W., Keliat, B. A., \& Pasaribu, J. (2016). Prinsip dan praktik keperawatan kesehatan jiwa stuart. Edisi Indonesia. Singapore: Elsevier

22. Pardede, J. A., Sirait, D., Riandi, R., Emanuel, P., \& Laia, R. (2016). Ekspresi Emosi Keluarga Dengan Frekuensi Kekambuhan Pasien Skizofrenia. Idea Nursing Journal, 7(3), 53-61. https://doi.org/10.52199/inj.v7i3.6446

23. Sitanggang, R., Pardede, J. A., Damanik, R. K., \& Simanullang, R. H. (2021). The Effect Of Cognitive Therapy On Changes In Self-Esteem On Schizophrenia Patients. European Journal of Molecular \& Clinical Medicine, 7(11), 2696-2701.

24. Oktiviani, D. P. (2020). Asuhan Keperawatan Jiwa Pada Tn. K dengan masalah Gangguan Persepsi Sensori: Halusinasi Pendengaran di Ruang Rokan Rumah Sakit Jiwa Tampan (Doctoral dissertation, Poltekkes Kemenkes Riau).http://repository.pkr.ac.id/id/eprint/498

25. Pardede, J. A., Irwan, F., Hulu, E. P., Manalu, L. W., Sitanggang, R., \& Waruwu, J. F. A. P. (2021). Asuhan keperawatan Jiwa Dengan Masalah Halusinasi. $\underline{10.31219 / \text { osf.io/fdqzn }}$

26. Pardede, J. A. (2020). Beban Keluarga Berhubungan Dengan Koping Saat Merawat Pasien Halusinasi. Jurnal Ilmu Keperawatan Jiwa, 3(4), 445-452. https://doi.org/10.32584/jikj.v3i4.671 
